Summer 2013

\title{
On the Politics of Societal Constitutionalism
}

Emilios Christodoulidis

University of Glassgow, Emilios.Christodoulidis@glassgow.ac.uk

Follow this and additional works at: https://www.repository.law.indiana.edu/ijgls

Part of the Constitutional Law Commons, International Law Commons, and the Law and Politics Commons

\section{Recommended Citation}

Christodoulidis, Emilios (2013) "On the Politics of Societal Constitutionalism," Indiana Journal of Global Legal Studies: Vol. 20 : Iss. 2 , Article 5.

Available at: https://www.repository.law.indiana.edu/ijgls/vol20/iss2/5

This Symposium is brought to you for free and open access by the Law School Journals at Digital Repository @ Maurer Law. It has been accepted for inclusion in Indiana Journal of Global Legal Studies by an authorized editor of Digital Repository @ Maurer Law. For more information, please contact rvaughan@indiana.edu.

\section{$\Psi$}

JEROME HALL LAW LIBRARY

INDIANA UNIVERSITY

Maurer School of Law
Bloomington 


\title{
On the Politics of Societal Constitutionalism
}

\author{
EMILIOS CHRISTODOULIDIS*
}

\begin{abstract}
This paper is an internal critique of the theory of societal constitutionalism as developed by Gunther Teubner, with a specific emphasis on the constitutional and the political dimensions of the theory. As critique it focuses on the arguably unacknowledged dangers of co-option: the danger that constitutionalization, as an ongoing process, undercuts what we typically associate with the constitutional, which is its framing function; that this problem is accentuated when it comes to the transnational; and that its reflexivity runs the danger of market capture, in which case it remains only nominally political. The danger of market capture for societal constitutionalism is that the market becomes the means of calling forth the "societal" by submitting it to functional imperatives and, in the final instance, harnessing it to market allocations. This paper is, however, also an internal critique, because it, too, relies on the key concept of reflexive self-definition, aspiring to think it on an uncompromisingly political register.
\end{abstract}

\section{INTRODUCTION}

Older constitutional problématiques of a more romantic radical bent typically returned to the promise of constituent power to address the following question: If a political society or collective is that which acts through rules of ascription, to what extent can that ascription remain reconfigurable, reflexive, alive to redefinition, and open both to operationalization and transcendence by the collective that it names? This is of course also the problématique of Marxism, of a certain Marxism, that self-consciously places the subject of emancipation in media res, both bound to the modalities of an ascription that cannot be stepped behind while at the same time holding on to the promise of an overcoming and genuine reflexive process of self-definition. If self-definition appears a million miles away from our current stunned

* Professor of Legal Theory, School of Law, University of Glasgow, UK.

Indiana Journal of Global Legal Studies Vol. 20, Issue 2 (2013)

(C) Indiana University Maurer School of Law 
impotence before the financial meltdown, the theory of societal constitutionalism promises to carve out some space for reflexivity amidst the debris. It promises this by severing off the constitutional from the state and returning it in capillary form as appropriate to the logic of social fields. With an eye both to the constitutive and the limitative dimensions of constitutionalism, Gunther Teubner asks for a reorientation of constitutional language away from the state and toward the self-organization of functional spheres. ${ }^{1}$ It is only through such reorientation that the "growth compulsions" and expansionist tendencies of systems, crucially that of the economic system that has ravaged society, may be reined in. Since "every function system defines its own identity for itself . . through an elaborated semantics of self-ascription of meaning, of reflection, of autonomy,"2 Teubner says, quoting Niklas Luhmann, the question for societal constitutionalism becomes this: Can external pressure be exerted on the subsystems of such force that the self-limitations of their options for action will take effect in their internal processes?

Such autolimitative, "system-internal" reflection-conceptualized as constitutionalization-can be initiated and mandated externally-politically and legally — but cannot be substituted for. That is why an external political determination of transnational social subconstitutions is not feasible. Only constitutional irritants, i.e. political impulses to constitutionalize, are possible. "The fundamental problem" to which societal constitutionalism is the answer is the following, according to Teubner: "How is it possible to increase external pressure in order to stem the negative externalities of autonomous subsystems by means of their internal self-limitation?"3 His answer, as will be explained in more detail below, is that the "subsystems' own selflimitation" involves tapping resources of reflexivity and instigating internal processes of selection, whose impetus is sustained externally but processed internally in the form of an "internal politicization," as constitutively directed to the question of the public interest.

"This is the message of societal constitutionalism. Any global constitutional order is faced with the task: how can a sufficiently large degree of external pressure be generated on the subsystems to push them into self-limitations of their options?"4 With an eye both to the

1. Gunther Teubner, Constitutional Fragments: Societal Constitutionalism AND GLOBALIZATION (2012).

2. Gunther Teubner, A Constitutional Moment? The Logics of 'Hitting the Bottom', in The Financial Crisis in Constitutional Perspective: The Dark Side of Functional DifFerentiation 3, 14 (Poul Kjaer, Gunther Teubner \& Alberto Febbrajo eds., 2011).

3. TEUBNER, supra note 1 , at 41 .

4. Id. at 84 . 
constitutive and the limitative, Teubner asks both questions in tandem: Not only what are the institutional preconditions of the autonomy of functional subsystems, but also where are the limits of their expansion? One has to begin from the "constitutive" dimension of the self-foundation of systems in order to understand the options available to rein them in. For Teubner, the constitution of the economy, science, the media, etc.,

perform the same constitutive function by securing for each sphere the autonomy of their specific medium, today on a global scale. Each partial constitution makes use of "constitutive rules" to regulate the abstraction of a homogenous communicative medium-power, money, law, knowledge-as an autonomous social construct within a globally-constituted function system. At the same time the constitutions make sure that the society-wide impact of their communicative media is guaranteed under different historical conditions. They develop organizational rules, procedures, competences, and subjective rights for both these orientations, codifying the separation between the social spheres and, in this way, shore up the functional differentiation of society. ${ }^{5}$

While "high cognitive demands" will be made of "national and international interventions by the world of states," especially in a situation of economic crisis, the temptation must be resisted to substitute their-the states'-reason for that of the focal system, here the economy. ${ }^{6}$ Instead, their intervention should consist of the selective generation of "constitutional irritants" that will translate into self-steering and that will liberate systems from pathologies in the form of "self-blockades," but not superimpose state rationality. ${ }^{7}$ State-run command economies, is the (not so) implicit message, failed for attempting such a substitution, and buttressed the failure with state terror-hence Teubner's warning that "following the experiences of political totalitarianism in the last century, a permanent subordination of the subsystems to the state is no longer a valid option." 8 Hence there is "no alternative but to experiment with constitutionalisation," in the hope that, "with a bit of luck," "the external and internal programmes"
5. Id. at 75-76.
6. Teubner, supra note 2 , at 14
7. Id. at 14-15.
8. Id. at 13 
of irritating and irritated systems" will "play out together along the desired course." 9

This paper raises the reflexive question of what is societal about societal constitutionalism. And it raises it against what we might describe as the danger of double slippage. The first dimension of slippage concerns the constitutional: the conscious and incessant distancing of societal constitutionalism from any debt to-or leverage from-the political or state systems threatens to undercut its constitutional grounding and send it into free fall. If, as we will see, the constitutional reflexivity of social spheres depends on a (metalevel) coupling with law, the question for the constitutional is what work the law can do to sustain the reflexivity of the system with which it is coupled. The second dimension, more insidiously, involves the danger of market capture, whereby the market calls forth the societal by submitting it to functional imperatives, and, in the final instance harnessing it to market allocations. I want to insist on the formulation "final instance" here, for there is no direct link between functional imperative and market allocation. But I will argue that functional equivalence, at some level, involves a comparability that it secures through the market, no longer as arbiter of economic value, but of value simpliciter. In the face of the double slippage, any envisaged response to the crisis runs the risk of remaining either muted or co-opted, respectively.

The paper positions itself as an internal critique of the theory of societal constitutionalism as developed by Teubner. It is critical because I focus on what I will argue are, often unacknowledged, dangers of co-option: the danger that constitutionalization, as an ongoing process, undercuts what we typically associate with the constitutional, which is its framing function (Part III); the danger that this problem is accentuated when it comes to the transnational (Part II); and the danger that its reflexivity submits to market capture, in which case it remains only nominally political (Part IV). If the paper is, however, an internal critique, it is because it too borrows the key concept of reflexive self-definition, aspiring to situate it on an uncompromisingly political register (Part V). First, however, a few caveats will be presented (Part I).

Before that, let me preempt an objection, even if at this stage I can do no more than flag it. Perhaps the most controversial aspect of my argument about societal constitutionalism is the normative prescription of insisting on the necessity of an irreducible political dimension. There are two key terms here, "irreducible" and "political." By "irreducible" I

9. Id. at 15 . 
mean not convertible into the coding of the receiving system. My worry about societal constitutionalism, and my fundamental difference with Teubner, is that any assumed dialectic between external and internal politicization collapses too quickly into the latter pole, if the premise of functional differentiation, as guarantor of nothing short of the autonomy of spheres of action and thus freedom, is treated in all cases as non-negotiable. Under conditions of complete functional autonomy, what is political about internal "politicization" is a question for the social subsystem, and only for the social subsystem, to answer. My suggestion is that such enfolding be "ruptured" in the only way it can be, which is externally, i.e. politically. In what sense to understand "politically?" With this question, we turn to the second of the key terms. There is a temptation, one that Luhmann himself would rarely resist, to recall the state alongside any reference to the political. But systems, according to Luhmann and Teubner, are first and foremost systems of meaning, phenomenological reductions that allow for the emergence of communicative fields. In this reduction and this emergence, the semantics of the state have been significant for the consolidation of the political system, orienting and organizing meaningful communication around those semantics. Democracy too, in the process, has been thematized in terms of the difference between government and opposition, a super-coding that for Luhmann gradually displaces alternative "distinctions directrices." But it would be wrong to treat all this as anything but a historical, contingent development, especially under conditions of globalization where the state is called on to play an increasingly selective role in its relation to capital in the consolidation of the global system. The locus of the political has always also been in the contestation of such renderings of public space and such conceptualizations of power distributions, and this reflexivity is constitutive of the meaning of the political.

Let us not lose sight throughout this of the critique of "the self-ascription of meaning," and a critique of that critique. It is in the context of the promise of a special kind of reflexivity that systems theory can be understood as critical theory. We therefore must relate it, as an internal critique, to the double danger that we saw confronting societal constitutionalism: on the one hand, a "constitutionalism" so under-determined as "constitutionalization" that it fails to perform any "gathering" work at all; and on the other, a concept of the "societal" that surrenders constitutionalism, constitutively, to the logic of price. 


\section{THREe CAVEATS}

\section{A. Crisis as Opportunity}

Explicit in Hitting the Bottom, ${ }^{10}$ and implicit in Constitutional Fragments, is the spectre of crisis. How is systems theory poised at this historical conjuncture, before the dynamics of societal subsystems spinning out of control? Teubner's insistence on the limitative has an important role to play when "tipping points" are reached, in which case a reaction cannot help but be generated. In the face of impending catastrophe, the constitutive dynamics of systemic augmentation will be reined in, and subrationalities-systemic, partial-will yield to the requirements of an overall limit. Constitutionalising Polycontexturality, ${ }^{11}$ for example, culminates in an argument and a warning about preventing "catastrophe." Teubner's concern is that "freed up energies" may "spin out of control," to have corrupting or even destructive social effects, when a "tipping point" may be reached, at which we may even have a "collision" between the reproduction of function systems and a "comprehensive rationality of world society." 12 "This requires massive interventions," he says, most effective when they "are translated into self-limiting impulses and transformed into a regime constitution." 13 I would ask this question: How would we know that tipping points have been reached and that destructive energies can no longer be tolerated? What societal register would carry that message? Not just from Marx, but from Polanyi too, we know that the market system has had a series of massive collisions with society, and what, in Marx's analysis of capitalism's early clearing exercise of "primitive accumulation," is a history of pillage, exaction, and devastation, Polanyi describes as the radical disembedding of the market system from the society that harbored it, a violent extraction that marks social devastation. Worlds have been lost in these collisions, and not only was no "tipping point" reached or registered, but in some cases, in the colonial context for example, there is not even a trace of the language that the vanquished used to describe the loss of their worlds. That is all to say that functional subsystems outlive catastrophic events. In which case, "tipping point" disasters are reintegrated into business-as-usual, giving those responsible for the crisis yet another financial instrument to play with, recycling catastrophe into the vortex

10. Teubner, supra note 2.

11. Gunther Teubner, Constitutionalizing Polycontexturality, 20 Soc. \& LEGAL STUD. $210,210-29$ (2011).

12. Id. at 225 .

13. Id. 
of profit as another toxic commodity to be sold. We witness a functionalization in the direction of new systemic operations and a renewed impetus. This is too depressing and familiar a point to develop at any length. It is also an argument that resonates all too disturbingly with how systems "think."14 Take the Europe 2020 Strategy put forward by the European Commission as successor to the 2000 Lisbon Strategy, setting out a vision of Europe's social market economy for the twentyfirst century. The strategy aspires to "show how the EU can come out stronger from the economic crisis and how it can be turned into a smart, sustainable and inclusive economy delivering high levels of employment, productivity and social cohesion." 15

If crisis is an opportunity to "come out stronger," then we need a different word to describe the situation in Greece, where the cases of HIV rose by over 1000 percent in the first six months of 2012 in Athens, where Greece's already anemic health budget was slashed by 40 percent last year, and where public suicides are regularly reported in the media.

This first caveat is merely an invitation not to be hasty in envisaging paradigm shifts; capitalism has proven extraordinarily resilient in the past. Perhaps the only thing that might usher in radical change will do so not because it is read (and reacted to) by the paradigm it challenges but precisely because it cannot be. But that is a different argument. For now let us just say this: as is always the case in the deployment of collective categories, the notion of a collective "hitting the bottom" is both over- and under-inclusive. The crisis is a catastrophe for the lives and livelihoods only of some. There are indeed many who are angry (references in the literature abound to Durkheim's "colère publique"), but there are also those who remain largely untouched or even who have profited from the crisis. And then, of course, there are those who are well past the "tipping point," for whom it is already too late.

\section{B. State Phobia}

Here is a short extract from Foucault's 1979 series of lectures at the Collège de France:

Against this the inflationary critique of the state, against this kind of laxness, I would like to suggest some

14. Gunther Teubner, How the Law Thinks: Towards a Constructivist Epistemology of Law, 23 L. \& Soc. REV. 727 (1989).

15. As per José Manuel Barroso, President of the European Commission. See Europe 2020, EUR. COMM'N, http://ec.europa.eu/europe2020/index_en.htm (last visited Oct. 1, 2013). 
theses ... In the first place there is the thesis that the welfare state has neither the same form, of course nor, it seems to me, the same root or origin as the totalitarian state, as the Nazi, fascist or Stalinist state. I would also like to suggest that the characteristic feature of the state we call totalitarian is far from being the endogenous intensification and extension of the mechanisms of the state; [the totalitarian state] is not at all the exaltation but rather the limitation, a reduction and a subordination of the autonomy of the state, of its specificity and its specific functioning ... in relation to something else, which is the party. ${ }^{16}$

While Teubner too identifies the role of the party as key to "totalitarian societal constitutions" 17 and remains ambivalent rather than damning the "precarious balance" attempted by the welfare state, ${ }^{18}$ there surfaces in the later work a certain impatience with forms of direct steering by the state of "social suborders" that too quickly turns to a rejection of "statist" societal constitutionalism. With the shadow of totalitarianism rarely far away, a certain phobia displaces a more careful scrutiny over the threshold of appropriate steering. In any case, let us not too hastily give up faith in the state as an instrument of steering; otherwise societal constitutionalism can too easily turn into a dystopia with consumer activity substituting for democratic engagement and the public sphere a version of Walmart writ large.

\section{Polanyi and the "Double Movement"}

"In the long run, [ the one-sided 'neo-liberal' reduction of global constitutionalism to its constitutive function cannot be sustained. It is only a matter of time before the systemic energies released trigger disastrous consequences. . . . This is the moment when Polanyi's 'double movement' makes its presence felt."19 Polanyi, as is well known, does indeed identify a reactive double movement at what Teubner calls the "tipping point," with social forces storming the market to reverse the radical disembedding of the economy from society. ${ }^{20}$ But what would "disembedding" mean under conditions of functional differentiation?

16. Michel Foucault, The Birth of Biopolitics: Lectures at the Collège DE FRANCE 190 (Michel Senellart ed., Graham Burchell trans., 2008).

17. TEUBNER, supra note 1 , at $21 \cdot 23$.

18. Id. at $24-26$.

19. Id. at 78.

20. Karl Polanyi, The Great Transformation (1944). 
Where will society draw the resources for that storming with the purchase point for a society-wide response dispersed and with its ability to respond to market excess undone? In what modality would society "collect" itself, and what form of action would its response take? These are important concerns and they make recourse to Polanyi hugely problematic. Let me lay out two of these concerns because they relate directly to the "societal" portion of "societal constitutionalism." For Polanyi, there is a significant continuity between functional differentiation and what he identifies as the "disembedding" of the economy from society. And perhaps that is why Polanyi is not the most obvious ally for those that see the problem only at the threshold at which functional differentiation has gone too far. At a certain threshold of functional differentiation, significantly lower than what we take now as "hitting the bottom," societies withdraw meaningful symbols that gather social meanings, value systems, or constitutive commitments; values under conditions of differentiation are too poorly selective (Luhmann also says this) to sustain identifications and inform commitments that sustain "embeddedness."

Where to place the threshold? The difference that Polanyi emphasizes, as is well known, is that between the market and the market system. Throughout history, economies have involved markets: the Great Transformation's early chapters are dedicated to describing embedded forms of market activity. ${ }^{21}$ The monumental shift comes with the creation of markets in land, labor, and money. It is the generation of markets in these three "fictitious commodities" and the articulation of these three markets that create the market system and the great transformation. The dubious achievement of this articulation is the collapse of the notion of the political economy into its market form. The generalization of the logic of the commodity across spheres so vital to societies marks the moment of disembedding. It is important to focus on this complementarity above all, the facets of the articulation, and the destructive commodification that propels itself forward through these linkages. From a systems perspective, although I cannot develop this hypothesis further, it is the creation of a market in money, and its articulation with the other two dimensions of marketization, that allows the "hypercyclical" linkage ${ }^{22}$ and self-referential closure of the economic system as market system, differentiated because it is disembedded from society, and as undercutting the political economy. So, and this is my second concern, the optimism is misplaced that somehow social forces will come to the rescue again to rein in the more radical and

21. Id.

22. For the notion of the "hypercycle" and its role in the self-referential closure of autopoietic systems, see GUNTHER TEUBNER, LAW AS AN AUTOPOIETIC SYSTEM 25 (1993). 
catastrophic aspects of the disembedding of its economy that have left society denuded, stripped of all protections. "Polanyi very pertinently defines socialism as the subordination of the economy to society and of economic goals to the societal goals which encompass them and assign them their subordinate place as means to an end." 23 All of which points to the observation that we should simply concede that Polanyi is an unlikely ally for societal constitutionalism. His is ultimately an argument grounded in solidarity as irreducible ground. As Europe watches over the pauperization of its peoples at its periphery with renewed dispatches of austerity measures, is anyone really under any illusions over what economic solidarity meant and means to the European Union? And if for a moment we assume the European Union's oversight is benign, what forces of solidarity could be marshaled under current conditions of functional differentiation? While Polanyi's diagnosis—of the disembedding of the economy from European society-is painfully relevant, his prescription is painfully unavailable.

With these caveats in place, we now turn to the concept of "transnational societal constitutionalism" to ask questions of each of its terms, as they articulate together.

\section{UPLOADING THE TRANSNATIONAL}

"Globalization," says Teubner,

above all means that functional differentiation, first realized historically within the nation states of Europe and North Africa, now encompasses the whole world. Certainly not all subsystems have globalized simultaneously, with the same speed and intensity. Religion, science and the economy are well established as global systems, while politics and law still remain mainly focused on the nation state. ${ }^{24}$

Teubner further states, "[T]he staggered nature of globalisation produces a tension between the self-foundation of autonomous global social systems and their political-legal constitutionalization."25

Teubner raises the question of this "tension" to point out that the "constellation" that was possible in the nation-state between law,

23. ANDRE Gorz, CRITIQUe of ECONOMiC REASON 130 (Gillian Handyside \& Chris Turner trans,, Verso 1989) (1988).

24. TEUBNER, supra note 1 , at 42 .

25. Id. at 43 (emphasis omitted). 
politics, and the regulated field (subsystem) has come undone; that there is "no counterpart" to it "in the global context"; and that "global self-foundation and national constitutionalization-the global economic and the national political, for example-are irrevocably drifting apart."26 The answer to such an irrevocable development can only be for the global function systems to develop their own constitutions. As we will see, legal structures will have a role to play in this. "But . . . the discrepancy between globally established social subsystems and a politics stuck at inter-state level" can only lead to "the constitutional totality break[ing] apart" to be "replaced by a form of constitutional fragmentation." 27 "The comprehensive structural coupling" that Luhmann famously identified in the constitutions of nation-states in modernity, "clearly has no equivalent at the level of world society." $28 \mathrm{We}$ have instead a "new phenomenon: the self-constitutionalization of global orders without a state."29 There are benefits and risks in the new constellation and the distancing between "societal" and "state constitutions." Less marked by a dependency on "the power of states, state policies and the ideologies of political parties," societal constitutions will inevitably, however, be tightly coupled to "interest constellations within the global fragments." In a positive vein, this "should result in a greater responsiveness to social needs than the constitutional law laid down by state authorities." 30 The risk, on the other hand, is that an excessively close coupling of societal constitutions to "partial interests" may lead to "corrupt" constitutional norms. It remains to be seen, says Teubner, whether countervailing influences from institutions and civil society will balance out the risk of corruption, though that is very much the normative drift of his argument. ${ }^{31}$ This is an important question, and the book lends significant insight to it. But, for now, I will not move in that direction. Instead, I want to stay here with the diagnosis that there is no equivalent of the constitutional, as a coupling of politics and law, at the global level; with the identification of what might replace it at the global level; and with the assumption that with the new societal form of "self-constitutionalisation of global orders," the constitutional function might be uploaded from national to global level. If the emphasis here is on constitutional function as definitive of what it is to have a constitution, it is because Teubner's is, too. We are working here with functional definitions and

\footnotetext{
26. Id. at 44 .

27. Id. at 51 .

28. Id. at 52 .

29. Id. at 53 (emphasis omitted).

30. Id. at 54.

31. Id.
} 
understandings of the constitutional, with other possible, previous defining coordinates having come adrift. There are two ways to understand the modality by which the constitutional might be uploaded to the global level. One involves the language of generalization and respecification. The other, typical of functional analysis, involves looking at what functional equivalents (to the national constitution) uphold functional differentiation and the autonomy of social systems at the global level, crucially in respect of both their separateness and their connectedness, the latter in terms of mutual cognitive adaptability and coevolution. Let us look at both in turn. The uses of the dialectic of generalization and respecification - as the modality of abstracting and uploading the constitutional-mainly regard the use of fundamental rights. To explain the dynamic of the emergence of fundamental rights for the "world society," Teubner asks what elements might be generalized from the tradition of nation-state constitutionalism that might be respecified in the global context of advanced functional differentiation.

Generalizations are of course as much selective suppressions as they are selective actualizations. The "reflexivity" of the system navigates what is suppressed and what is actualized in the uploading of rights to the global level, through the double movement of generalization (away from the context of the nation-state) and respecification (as appropriate to the receiving fields). What guides this reflexivity is the handling of the tension between what is generalizable as constitutional (categorical, transcendent) and what is appropriate framing, sensitive to the self-production of the field. ${ }^{32}$

Of course, Teubner will rightly insist that the "constitutional emptiness of the transnational is a false assumption." 33 What exaggerates the claims to constitutional novelty is that "an equivalent to the constitutional subject of the nation state is not so easily recognizable at the transnational level." ${ }^{34}$ But in a space populated by new "assemblages, configurations and ensembles," the relevant constitutional question is whether these "exhibit sustainable analogies to the nation state" in terms of constituent power, collective

32. I have suggested elsewhere that it is impossible to negotiate this tension. It immediately folds into self-reference and then collapses into the second pole, in the sense that re-specification overdetermines what might be generalizable in the first place. Emilios Christodoulidis, Of Boundaries and "Tipping Points": A Response to Gunther Teubner, 20 SoC. \& LEGAL STUD. 238, 240 (2011).

33. TEUBNER, supra note 1 , at 7 .

34. Id at 8. 
self-definition decision-making and organization. ${ }^{35}$ "Generalization" and "respecification" are key to tracking the sustainable analogies.

Teubner has developed these ideas in an argument that circumvents many of the difficulties surrounding "horizontality" and the efforts of deploying human rights to curb the power of private actors in the global field. ${ }^{36}$ And he is surely right in the limiting function he attributes (elsewhere) to human-rights-constitutionalism, as a compensatory (my term, not his) constitutionalism, with human rights simply existing as markers of excess, signs that the ordinary operations of the system have imposed social costs beyond a threshold of what the system deems bearable, or that it can usefully externalize. ${ }^{37} \mathrm{I}$ will not delve into it further because with Constitutional Fragments, the ambition has been raised to a full-blown theory of reflexive constitutionalization. The reflexivity is geared to the maintenance of proper boundaries, of a balance of the constitutive and the limitative such that the sphere of autonomy of social subsystems is maximized and functional differentiation is secured at the global level. Remember that it was the asymmetry, or staggering, between systems that went global (economy) and systems that haven't (legal, political) that the new fragmentary constitutionalization is called on to redress in a way that might replicate the balances and proper limits secured by "functional differentiation, first realised historically within the nation states of Europe," now on the global scale. If functional differentiation was sustained through a system of structural couplings, a coevolution through a complex logic of linkage between autopoietic systems, the endeavor now is to replicate such complex couplings at the global level where certain systems lag behind in terms of what systems theorists call "performance," i.e., their impact on other systems in the direction of securing the overall reproduction of society.

Yet, this endeavor stumbles on what is, at least prima facie, problematic about uploading the familiar pattern of mutual irritation and adjustment from the national to the supranational level. It is precisely the effect of the asymmetry between the economy and the legal-political complex, in other words, between the transnationalization of markets and that of states. This asymmetry is not contingent, a lagging behind that can be accelerated and brought up to speed, but is instead structurally built-in to the architecture of global capitalism. In the case of Europe, the asymmetry shows in the unevenness of the integration of national markets (through the fast-tracking of economic

35. Id.

36. Id. at $124-49$.

37. Gunther Teubner, The Anonymous Matrix: Human Rights Violations by "Private" Transnational Actors, 69 MOD. L. REV. 327, 329-30 (2006). 
integration) as against the fragmentation of states' systems of social protection. At the level of "world society," it is seen in the hugely successful creation of "global turbo-capitalism" against the multifragmented processes of political transnationalization. In each case, the asymmetry is vital and productive for the integration of capital and the extraction of profit.

Let us look at this in systems-theoretical terms. The effect of the asymmetry is the uneven distribution of "irritation-capacity" between the economic and political systems at the global level: economics overwhelm, politics underwhelm. The transnational is already largely colonized by the economic logic it is supposed to "impact" on. The idea that an (economically-colonized) transnational system, whose very logic of connectivity (the "trans" of the transnational) plays out that of competition and comparative advantage, might nevertheless act to rein in what sustains it is in fact paradoxical. We are depressingly familiar with the ways in which the transnational is organized along the lines of managing "preparedness for the market"-through the "un-protecting" of labor, the suppression of wages and undercutting of trade unionism, the rolling back of the main costs of labor reproduction back onto labor, the abiding by World Bank governance manuals, and the rest. The relation between capital and states is crucial here, and the asymmetry propels the creation of margins of profit in terms of the "race to the bottom," where social protection afforded by states is a cost and where any attempt to hoist that protection above the national level (social chapter, social charter, social rights, social dialogue) is systematically undercut (when it was not so toothless in the first place as to merit attention). Spectacularly here, more than any other sphere of legal thinking, the reflexivity of the legal and political systems is short-circuited back into the market paradigm by taking for granted the "redundancy" of "codetermination" as an organizing principle of production and by replacing the "old ways" of thinking about labor with optimizing the regulation of the labor market, at best through an enhancement of "capabilities." For the most part, labor lawyers appear incapable of thinking past labor market optimization. Relations between core and peripheral states are a vital part of the "rationalization" of the transnational, an edifice which is premised on power asymmetries. In the meantime, the systematic pauperization of the periphery-its asphyxiation under austerity-daily jettisons large numbers of skilled and semi-skilled workers into what used to be called the reserve pool of the unemployed to compete for casual labor with the ever-increasing flows of illegal immigrant labor. The pattern is generalized across the board, always driven by the demand of maximization of financial returns, and in each case respecified to the institutional logic of the 
field. In his discussion of the "self-constitutionalization" of international organizations, Teubner picks the World Trade Organization (WTO) as "[o]ne well-known example [of] constitutional emancipation." 38 Here constitutionalization takes, among other "directions," that of giving "priority of trade rules over political principles" and of "direct effect." 39 The word "emancipation" is interesting here especially, as it consists of separating off the autonomous field of "trade rules" from "political principles." This "emancipation," which is undoubtedly a moment of "self-constitutionalization," entails the progressive dismantling of labor protection as an unavoidable effect of the global organization of trade that circumvents any possible municipal safeguards. A key moment of the "emancipation" is the Singapore summit of 1998, at which the WTO washed its hands of any involvement in labor disputes, thus relieving the regulation of international trade of its effect on the world's producers. But as we know, and Alain Supiot puts it pointedly, industrial relations, social protection, and employment and unemployment levels, among others, depend much more on the organization of international trade than on the policies of national governments, which, he argues, paradoxically makes the effectiveness of the protection of collective rights inversely proportionate to job security: those who need them most are effectively deprived of any recourse to them. ${ }^{40}$ Many of these examples can be discussed further, or explained otherwise or away, and the assessment of what political publics on the global scale might achieve cannot and should not be underestimated: global economic action inevitably generates global constituencies of addressees, and therefore also global challenges. Teubner returns to these themes often. He writes, for example, that

the dismantling of national barriers and an explicit policy of deregulation led to a ... global financial market constitution that set free uncontrolled dynamics. . . . Only with the near catastrophe we have experienced does it appear that collective learning processes will in future seek constitutional limitations. 41

I think this is important. But I am left with the question: If "learning processes" are indeed inaugurated, what precisely is to be learned at the constitutional level? Because if, as I have argued, the

38. TEUBNER, supra note 1 , at 55 (emphasis added).

39. Id.

40. Alain Supiot, Law and Labour: A World of Market Norms?, 39 NEW LEFT REV. 109 (2006).

41. TEUBNER, supra note 1 , at 11 . 
asymmetry that is key to "uploading" from national to transnational is structural and constitutive, then the learning processes can only take the form of pure negativity. If, that is, the logic of global capitalist expansion, as race to the bottom, pits the economic against the political systems, then the learning process can only assume the form of anticapitalist struggle. And I cannot imagine that this is what transnational societal constitutionalism would embrace as political prescription.

In any case, and whatever the meaning of "learning" in this context, my aim in this section was to identify an asymmetry that is constitutive of the logic of extraction of surplus value under conditions of globalization, and thus structural, and to insist on the consequence this has for systems theoretical analysis, namely that the thesis of mutual cognitive adaptability between systems relied on a symmetry that is now buried under a different principle of organization or differentiation. The problem is that the generalization of the political beyond the nation-state, the move from national to transnational politics, is significantly impacted upon, if not actually organized, by the economic logic it will then be called on to mitigate. The different logics of political and economic systems, whose mutual autonomy and reciprocal "irritability" is seen as that which maintains differentiation, and which is undercut at the transnational level since the political system at that level does not replicate the logic of state action but instead, the economic system, having successfully harnessed the state to a system of global competition, simply "exploits" it in the direction of its own aggressive expansion. Let us thus raise a doubt over the uploading of the "mutual irritability" thesis from the national to the supranational level. We will see later what key problem the "organizing asymmetry," as I have developed it above, causes at the metalevel of reflexivity at which we are invited to think though the regenerative impetus of societal constitutionalism. With this, we move in the next section from the "transnational" to the "constitutional" of "transnational societal constitutionalism"; the last of the three terms, the "societal," we will address in the final section.

\section{The Pitfalls of Constitutionalization}

"The agenda of transnational constitutionalism" involves not the "creation," but "rather the fundamental transformation of a pre-existing constitutional order." 42 My question here involves the temporal dimension and the idea of "constitutionalization" as an emergent

42. Id. (emphasis omitted). 
constitutional reality of the interplay, at the global level, of systemic logics to mutually limitative effect.

The learning processes with which we ended the previous section are a key aspect of the logic of societal constitutionalism, which captures something that is crucial: its reactive mode. The absence of a comprehensive coupling of politics and law at the global level results in forms of "constitutional fragmentation" where "occasional couplings can be seen as and when social problems demand. Constitutional norms are developed ad hoc when a current conflict assumes constitutional dimensions and requires constitutional decisions." 43 "When global problems are building up within global sectors, social conflicts emerge that result in individual legal norms of a constitutional quality. These norms then become aggregated, over time, into the constitutions of the subsystems of world society." 44

What to make of constitutionalization as reactive, the constitutional curiosity that is this incremental, aggregative, fragmentary process of becoming constitutional? I will identify in this section a certain tension in the argument about constitutionalization. On the one hand, I identify dangers that are insufficiently rebutted of a constitutionalization that appears as nothing but an a posteriori (incremental, fragmentary, aggregative, and so on) sanctioning of economic processes. On the other, I want to identify the resources that exist within the theory itself for resisting this appropriation of constitutional language, where the appropriation results in the buttressing and redeeming of global processes of capital accumulation. After all, "learning" does not occur in the receiving mode only; it involves a certain invariability of structures of expectations, as well, in terms of which information is received. It is in the selective yield of such expectation structures that learning occurs. It is here, above all, that we can identify the locus of a specifically constitutional reflexivity.

In the second chapter of his ground-breaking treatise Social Systems, Niklas Luhmann identifies three dimensions-social, material, and temporal-to all "meaning" constructed in social systems. ${ }^{45}$ Taking the cue from him, I will suggest three dimensions of the meaning of "constitutional." In the social dimension, the question is over the subject that the constitution names; in the temporal dimension, the question is over the constitution's ability to recruit the past in its expectation-binding operation for the future; in the material dimension, the question is over the threshold of unity that would gather the legal

43. Id. at 52 (emphasis added).

44. Id. at 53 .

45. See Nikilas LuHManN, Soclal Systems 59-102 (John Bednarz, Jr. \& Dirk Baecker trans., Stan. U. Press 1995) (1984) (explaining the three dimensions). 
system as a meaningful whole. These are threshold requirements for ascribing constitutional meaning because we associate with the constitution the constitutive functions of providing unity for the legal system, normatively binding certain key expectations for the future, and naming the subject of popular sovereignty. In this sense, they underpin and subtend any form of constitutional reflexivity. And it is under this prism that we need to look first at the dangers of constitutionalization as reactive, then at the promise, perhaps, of a selective, reflexive constitutionalization that crucially preempts and immunizes society from the more toxic effects of a runaway economy. ${ }_{46}^{46}$

The question for constitutionalization as a learning process, and as reactive, poses this problem for the "constitutional." If the term constitutional connotes the framing function I suggested and the constitution connotes a system of metarules that sanction systemic operations and frame the contours of what can be contested meaningfully therein, what does it mean to talk of constitutionalization as an ongoing process? And what does it mean to talk of constitutionalization at the transnational level, where constitutional functions appear to be distributed between the two levels, or claimed at both, with no jurisdiction over the distribution? If constitutionalism traditionally denotes a certain articulation of the political and the legal, where might one look now for the political register within constitutionalization, with the weakening or collapse of political opportunities of framing or intervention? Constitutionalization thus appears to beg the question on two important fronts, which is significant because it is constitutive of the constitutional in two directions, externally and internally. In the case of the legal system, the "external" dimension involves the articulation or coupling of the legal and the political; what appears to be begging the question about the coupling is that the political is not given expression to except a posteriori, and therefore, it appears as both condition and product of "its" coupling to law. The second involves the fundamental question of what gives law its systemic nature; in this context, it is question-begging to assume the hierarchization of jurisdiction or the framing function as taking place $a$ posteriori. Let us stay with this internal dimension.

The usual way out of these conceptual problems is recourse to one or another form of constitutional pluralism. But to call a constitutional order plural is, at least prima facie, contradictory. As Chris Thornhill thoughtfully put it in a recent critical review of theories of constitutional pluralism, the constitution is, after all, the "point of final

46. In the author's opinion, Teubner would not limit the discussion to the control of the economic system alone. 
normative regress" in the system. ${ }^{47}$ Such regress is what the systemic requires, and the systemic is the distinctive feature of the legal order. Even in the context of the common law and its insistence on the virtues of the ad hoc and the pragmatic, its most celebrated theorist, Herbert Hart, introduces the constitutional distinction between primary and secondary rules as constitutive of what it means to have a legal system. If he defines law as the "union of primary and secondary rules," 48 it is because secondary rules, rules of recognition, of validity, of change, and of jurisdiction, grant the body of rules their systematic character: recognition ultimately gathers the fragments (the disparate rules at the various levels at which they are instantiated) as one corpus, hierarchically structured and, in that sense only, rational. This rationality-as-systematicity finds its apogee in Kelsen. In both cases, and across the vast range that stretches between these two extreme positions, law is defined through its systematicity-its ultimate points of regress, the "rule of recognition," the Grundnorm, the basic constitutional principles-and thus against "plurality."

Of course "constitutionalization is a social process and only secondarily a legal process"; the great novelty of the theory is to withdraw any primacy of the legal. But, even as set adrift from the legal system, the meaning of the constitutional points to a certain function of "containment" along the social, temporal, and material axes mentioned above. These are threshold requirements for ascribing constitutional meaning. Uploaded to the level of "transnational societal constitutionalism," they become unsettled, as they become subject to a number of extraordinary reconfigurations in all three dimensions. In the "social dimension," because no constitutional subject can be ascribed as locus and agent of constituent power, the subject is fashioned out of the process itself, in a kind of backward projection; the a posteriori dynamic ascribes subjecthood to an actor as configured through the process, except no "fabulous retroactivity" looks capable of securing any semblance of such a subject along the spectra of transnational fragmentation of publics, or at least not yet. ${ }^{49}$ In the temporal

47. Chris Thornhill, Legal Pluralism: The Many Books on Europe's Many Constitutions, 21 SoC. \& LEGAL STUD. 413,420 (2012).

48. HeRBERT HART, THE CONCEPT OF LAW (1961).

49. To take this further: If no "demos" can be currently identified as subject of the process, the promise of an ever-closer union will deliver that subject. In a more speculative language, Jacques Derrida spoke of the "fabulous retroactivity" of such an operation of the future-anterior, and in theoretically less exciting, though no less exalted terms, Joseph Weiler speaks of the European project's messianic character. There is every reason to be more cautious in the current conjuncture. And yet, crisis-prone, bereft of ideals, limping from social to democratic deficit and back, driven by a vision of economic growth without economic solidarity, and somehow despite its best theorists' best efforts, the European 
dimension, one encounters no framing function, and, startlingly, no actual need for one: rather, all that is needed is a gradual solidification of what the process produces, constitutionalization, the depositing of constitutional "fragments." In the "material dimension," finally, one encounters a slow incremental process that reconfigures the identity of the system as the system goes on.

The example of European integration, a clear example of constitutionalization as an ongoing process, is a particularly worrying illustration of the danger of the undoing of the constitutional. Not that one would know that from the constitutional literature on the European Union! In fact, if the endeavor to fashion a constitutional project for Europe has involved an extraordinary effort as well as a series of much debated significant failures, constitutionalization has granted it a less explicit, if spurious, success. In the absence of any kind of leverage that the project might have gained from its various "constitutional moments," remarkable chiefly for being so remarkably anemic, theorists of European law have compensated for the absence of any recognizable expression of pouvoir constituant at the European level with novel theoretical constructions replete with functional equivalences. A dubious stretching of the constitutional imaginary has been largely successful in redefining the terms of the debate. The "European Constitution," directly defeated on political occasions, becomes associated increasingly with a slow incremental process of capital accumulation and a generalization of social protection as harnessed to the logic of competition, increasingly, in the current more ruthless phase of its acceleration, as comparative advantage. These are contingent developments, and there is no reason to generalize one's disillusionment with the European adventure to all cases of transnational constitutionalism. What they do illustrate, however, are the dangers we encounter with constitutionalization as a process of "becoming constitutional," the conditions of that process, and the criteria of ascription of constitutionality. But if my argument in this section aims to raise the theoretical question over "constitutionalization" as problematic from a constitutional point of view, it is also to identify key resources in the theory, whereby the

constitutional project now appears to have been extraordinarily successful in fashioning itself as a constitutional settlement $a$ posteriori. The name it gives the process of this "settlement" is constitutionalization. The name it gives to the radical disagreements that beset it is pluralism. In another paper, I argue that both constitutionalization and pluralism develop in tandem with, or even become locked into, processes of market expansion and recalibration that retain no connection to the democratic impulse that animated the constitutional discourse of the European project. See Emilios Christodoulidis, A Minefield of Misreckonings: Europe's Constitutional Pluralism, 14 CAMBRIDGE Y.B. OF EUR. L. 119 (2012). 
reflexive "constitutional" element within "societal constitutionalism" is deployed in the direction of a certain limitation of the generalization of economic value.

In a hugely suggestive reference to Reinhard Koselleck early in the book, Teubner directs us to the important question whether there is any significant distinction to be drawn between constitutionalization and (mere) juridification? What draws Teubner to Koselleck is the latter's attempt to "liberate constitutionalism from its limitation to the state and to extend it to all institutions of society." ${ }^{0}$ For us, what is of key importance is not that, but the following qualification Koselleck introduces: "constitutionalism should include all those institutions governed by law ... without which a political community is incapable of political action." Note the constitutive connection here between the constitutional, political community, and political action. For Teubner, Koselleck "leaves open" the question: "[W] hat is the difference between the constitutionalisation of civil society institutions and their mere juridification?" He answers it in this way: "In contrast to the simple juridification of social sub-areas, we may only speak of their constitutionalisation once legal norms have assumed the dual function ... of the foundation of autonomous orders and their selflimitation." "51 Like Koselleck, Teubner is concerned here with the invigoration of the institutions of civil society, what an older tradition of pluralism identifies as intermediate associations between society and state, and what Teubner defends in the name of functional differentiation: how the autonomy of spheres might be guaranteed; how their imperialist tendencies might be reined in; and how, given both the above, social integration may still be possible. ${ }^{52}$

This provides an answer to the danger associated with constitutionalization: that "self-descriptions," generalizations, and other emerging concepts and rules are merely aggregation rules or simply aggregations of rules whose constitutional function comes too late. They are gathering rationalizations that lack the constitutional qualities of being able to perform a framing function or a review function, that is, the hallmarks of the "constitutional" function, all of which would have required them to preexist the instance of their application. If, instead, the constitutional is to retain anything of the "constituent"-political dimension, of a society's ability to act on what the various spheres, regimes, or fields might present as the necessary logic of their self-production, then constitutionalization needs to be pitted against juridification, as it needs to be pitted against the generalization of

50. TEUBNER, supra note 1 , at 16 .

51. Id at 18 .

52. See id. at 20. 
economic reason. The very possibility of pitting anything against anything else, of setting up any set of "rationalities" as oppositional, involves resisting the enfolding of any injunction from the one into the logic of the other receiving system. In other words, it involves the capacity of a society to draw political distinctions and present political injunctions, and that is precisely what the dynamic of a creeping constitutionalization undercuts. And yet this is precisely what Koselleck insists on, and further insists on identifying as essentially constitutional: "constitutionalism should include all those institutions governed by law ... without which a political community is incapable of political action."

So with this we are at the heart of the ambivalence and the crux of the tension between constitutionalization as a reactive moment and constitutionalization as a reflexive moment. It is not enough here to argue that the two fall neatly on either side of the dialectic between internal and external politicization, because it is precisely the assumed "dialectic" underwriting the passage from external to internal that elides the tension and the opposition. If the injunction to protect the dignity of workers is nonnegotiable, then what would it mean to subject it to the criteria of internal politicization of the economic system, however loudly we proclaim that it should be done to protect the public interest, since economic reason cannot but operationalize arguments in terms of the exchange value of labor? We will say more about this in the final section. For now, let us simply repeat the problems relating to constitutionalization.

The danger of constitutionalization as self-limitation is that its success in underpinning the internal processes and keeping them in check is a contingent result of the emerging framing rather than its condition. If constitutionalization is merely the name of what "hardens" into concepts that acquire some form of orientation value for the system in response to societal stimuli (be they protests or conflicts) as it surges on along the trajectory of its self-reproduction, then we sacrifice the possibility to draw distinctions on a political-societal register. In the face of this surrender, and as the subsumption of value to the partial rationalities of the systems continues unabated, we should not be prepared to grace the institutional facilitation of the all too predictable trajectories of capital accumulation with the term constitutional.

But there is a second reading of constitutionalization that can be rescued from this fate. We find it developed in its complexity and intricacy in the fourth chapter of Constitutional Fragments, ${ }^{53}$ and I will visit it at greater length in the next section. On this reading, the

53. TEUBNER, supra note 1 , at 73 . 
constitutional imports a reflexivity that does not immediately yield to the functional imperatives of the economy, and the processes of learning remain fixed to a different normative register-I would call it political in a broader sense. This alone might hoist constitutional reflexivity out of the internal dynamics of partial rationalities and into a protective (limitative) role for society. From a systems-theoretical perspective, it is a highly difficult opposition for reflexivity to navigate between the normative and the functional. What purchase point exists for the "limitative" in the differentiated, centrifugal processes of social reproduction? What pivot exists for a reflexivity that might reflect on proper boundaries? What thresholds and benchmarks exist for that "proper" other than "functional," and what criteria exist for functional other than systemic equilibria that come in the form of "requisite variety" and other successful forms of bringing complexity under control? If any of these questions are to be answered in the direction of securing a "limitative" constitutional moment, then constitutional reflexivity must identify the point at which the system must yield before different sets of values or contract back to its proper limits. This would require a normative rather than a functional register, and, ingenious as Teubner's attempt is to run these as congruent and to navigate normativity via functional considerations, I cannot see how anything but a political reflexivity can secure society's protection from functional logics running amok.

\section{THE LEVELING Logic Of FunCTIONAL EQUIVALENCE}

A strengthened politics of reflection is required within the economy, and this has to be supported by constitutional norms. Historically it was collective bargaining, co-determination and the right to strike which enabled new forms of societal dissensus. In today's transnational organisations ethical committees fulfil [sic] a similar role. Societal constitutionalism sees its point of application wherever it turns the existence of a variety of 'reflection centres' within society, and in particular within economic institutions, into the criterion of a democratic society. ${ }^{54}$

Let us unpack the various elements of this formulation. Examples that Teubner gives of such instantiations (or "centers") of reflection are: political "activist" shopping ("the politicisation of the consumer"), "the

54. Teubner, supra note 2 , at 17 (emphasis added). 
ecologisation of corporate governance," and "plain money." What these examples share is that they allow systems to channel societal responses to their expansion in the direction of their own self-limitation. This "auto-limitative role . . . leads to the generation of powerful counter-structures: the limitation of power by power, money by money; in each case the system-specific medium turns against itself." 55 Take "plain money reforms," for example. "Plain money aims at the centre of the economic constitution because it configures-constitutes-the self-limitation mechanisms of the economy . . . it does not attempt to regulate the economy by means of political power, legal rules, moral imperative, [and] discursive persuasion." 56

These instances tap into broader and vastly richer resources of social dynamism. The first thing that the theory of societal constitutionalism brings to the fore is the interconnectedness of systemic phenomena with the underlying social dynamics as expressed in "constitutional arenas." Social conflicts, social movements, and social demands trigger at the subsystemic level processes that cannot be ignored, and to which institutional "solutions" offer nothing but temporary respite. The second thing to note, apart from the societal shadowing the subsystemic, is that subsystems react to contradictory dynamics building up within them. It is to alleviate such contradictory developments that constitutional reflexivity develops, as we will see, with the support of the legal system. In that sense, the "medial reflexivity" described above ("the limitation of power by power, money by money") is not yet constitutionalization; self-constitution is not yet constitutionalization. It is in need of further support. It only becomes "constitutional" in the form of a metacoupling, as supported by the reflexivity of law. As Teubner puts it:

What is the reason, though, why secondary legal rules are supplementing social reflexivity? Law comes into the self-foundation processes of social systems when they cannot fully accomplish their autonomy. This happens either when the social system cannot be adequately closed by its own first-order and second-order operations, or when reflexive social processes are unable to stabilize themselves or, especially, when they are becoming paralyzed by their paradoxes. In such cases, additional closure mechanisms come in to support the self-foundation of social autonomy. The law is one of

55. Id.

56. Id. at 16. 
them-not the only one, but one among several. The self-description of "state" acts as one of these closure mechanisms: The political system is only differentiable at all when it describes itself as a state. ${ }^{57}$

We will come back to this. For now, let us stay with what is troubling in the first extract that connects "reflection centers," "dissensus," and "democracy," not for the rather anemic opportunities that such instantiations of reflection such as activist shopping and "corporate social responsibility" present to the overpowering growth compulsions of the economy, but for the articulation of the notion of dissensus and the connection with democracy. The first and most troubling dimension is the logic of functional equivalence that it instills. "Reflection centers" are not democratic per se (that presumably would be submitting the economic to the political), but are functionally equivalent to democratic processes. Where "historically it was co-determination" that checked the growth compulsions of capitalist accumulation, now a "similar role"-functionally equivalent-is played by ethical committees in organizations. 58 The "growth compulsions" of modern corporate structures may be tempered by "external pressures" from political actors, but it is always the corporate structure that receives and deals with the democratic imperative or dissensus opportunity.

There are therefore none of the values that would have been engendered through the irreducible and incommensurable (therefore not functionally interchangeable) value of democratic participation (and contribution to social labor). Teubner, at times, appears to suggest that it would be a "category error" to "apply the decision models for politics, untested, to other social sectors," because it would install a "politics-led integration of diverging rationalities by imposing on them an internal 'political' constitution," and "wrongly politiciz[ing]" them. ${ }^{59}$ In any case, with the democratic (or at least with collective) decision-making relegated to the political system, we are left with functionally equivalent mechanisms; and through equivalence traverses merely a logic of instrumentality, of what opens up the space for productive, useful dissensus. This usefulness, again, will be measured in terms of what is conducive to maintaining proper balances between function systems, not in terms of the irreducible value of democracy. As we now move on to the much more complex argument about reflexivity and constitutionalization that Teubner offers us, let us retain from this

57. TEUBNER, supra note 1 , at 107.

58. Teubner, supra note 2 , at 17 .

59. Id. at 28-29. 
interim objection the distinction between the implicit and instrumental value of democracy and, for strategic purposes, the distinction between productive and incongruent dissensus. (I have suggested some uses for the latter in my Strategies of Rupture.) ${ }^{60}$

The analysis of constitutionality is highly innovative. Constitutional processes, says Teubner, are an example of "double closure" as suggested by von Foerster. ${ }^{61}$ "They are triggered when systems develop a second order closure, in addition to their operative first-order closure, by applying their operations reflexively to their operations." But this double closure depends crucially on a metalevel coupling with law. While the "constitutional," second-order closure finds expression in the system's reflexive structuring of its operations (for example, in politics, where power processes are directed via power processes-electoral procedures, competences, and fundamental rights), that reflexivity itself is the emergent property of a coupling with the reflexivity of law. Internally, that reflexivity is expressed as a coupling of first and second-order operations; externally, it is expressed as a coupling of the reflexive structures of the relevant system with the law. "Constitutions emerge when phenomena of double reflexivity arise-the reflexivity of the self-constituting social system and reflexivity of the law that supports self-foundation."62 Constitutions emerge when a structural coupling of the reflexive mechanisms of law (i.e., secondary rules) with the reflexive mechanisms of the relevant social sector occurs. Against Luhmann at this point, Teubner reserves the term constitutional only for the coupling of reflexive processes within both systems. Only this achieves the requisite density and permanence and ensures that we have constitutional coevolution of the two social systems.

The threshold of constitutionalization is only reached once the "hybrid binary meta-code" guides internal processes in both systems. ${ }^{63}$ This is achieved through the second-order coupling, with the help of "hybrid meta-codes," that is "codes" (the code-values: constitutional/unconstitutional) whose function is to allow the coupling of systems at the reflexive level (hence "meta"), and "hybrid" because in straddling the two systems there is no direct transferal of meaning between the two orders of reflection, but in each system the coding releases opportunities for system-specific thematization of what is constitutional or not in relation to the pursuit of the public interest. In the idea of the public interest and public responsibility as underlying

60. Emilios Christodoulidis, Strategies of Rupture, 20 L. \& CRITIQUE 3 (2009).

61. TEUBNER, supra note 1 , at 103 .

62. Id. at 104 (footnote omitted).

63. Id. at 110-11. 
the "additional reflection" imported at the constitutional level, we find the normative pulse of the theory.

This is how Teubner puts it in Constitutional Fragments:

The constitutional code of the social sphere concerned (constitutional/unconstitutional) is given precedence over the legal code (legal/illegal). What is special about this meta-coding, though, is its hybridity, as it takes precedence not only over the legal code but also over the binary code of the function system concerned. Thus it exposes the binary-coded operations of the function system to an additional reflexion regarding whether or not they take account of the subsystem's public responsibility. ${ }^{64}$

The importance here of constitutionality is that, as a hybrid metastructure, it enables a coupling at the metalevel and with it the productive maintenance of dissensus. It enables a heightened level of additional reflection. Not least amongst the functions of dissensus is the role that it plays with regard to the "auto-limitative" moment in protecting the blind reproduction of systems from reaching crucial thresholds between productive and catastrophic expansion. But this is only one of the effects of reorienting and controlling the self-reproduction of systems in the direction of serving the common good. And it is here that a claim for the politics of societal constitutionalism is articulated and defended "outside institutionalised politics" but, Teubner insists, no less robust for that. How to understand this form of politics? For Teubner, the "political" means two things: first, the political refers to the institutionalized politics of states; second, the political refers to politics in society outside institutionalized politics, in other words, to the "internal" politicization of the economy itself and that of other social spheres (i.e., the politics of reflection on their social identity). Here, social systems are dealing with their own founding and decision-making paradoxes-a process that can never be determined "technocratically." In this respect, the independent constitutions of society beyond the state are highly political. Reclaiming la politique for the forms of societal, extra-state reflection, he explains that "[s]ocietal constitutionalism effectively calls for sites of political reflection to be firmly established in the spontaneous sphere and in the organized sphere of the economy." 65 "Politicizing consumer preferences, ecologizing

64. Id. at 110.

65. Id. at 119 . 
corporations, and placing monetary policy in the public domain-these three constitutional arenas illustrate to what degree the 'internal' politicization of social subsystems depends on the specificities of their communicative medium." 66 For this very reason, the difference to their "external" politicization by state institutions must not be leveled. Societal constitutionalism opposes the centralization of fundamental sociopolitical issues in the political system. Its concern is to multiply the sites where controversies are fought and decisions made about "the political" in society.

And Teubner quotes Fischer-Lescano and Renner approvingly when they say:

This makes the administrative apparatus of public and private regimes more responsive to the social substrate, i.e. to world society itself (and not to its political system, the international community of states). It integrates it into the process of creating modes of action, and connects decision-making (in the legislative, executive and judicative apparatuses) and debate (among different global publics) with one another so that the duality between spontaneous and organized spheres in the formation of a social constitution-so significant in terms of the theory of democracy-can be established. ${ }^{67}$

I find exaggerated both the optimism of this extract and the responsiveness it suggests. Constitutionality as metalevel reflexivity neither underwrites nor guarantees the passage from external to internal politicization (in other words, the "responsiveness" proclaimed in the extract). It merely holds up the incommensurable logics of spheres to scrutiny and indirectly only, I would argue, restores, to return to Koselleck, "the ability of a political community" to engage in "political action." In the final section, and in the mode of internal critique, I will attempt to link constitutional reflexivity back to its political dimension.

\section{CONSTITUtional ReFleXivity as POLITICAL}

Let us take a different, political route into societal constitutionalism to test a certain hypothesis. On this other route, I will assume,

66. Id. at 121.

67. Id. at 123 (quoting ANDREAS FISCHER-LESCANO \& MORITZ RENNER, EUROPÄISCHES VERWALTUNGSRECHT 370 (2011)). 
relatively uncontroversially I hope, democracy as the organizing principle of the political and equality as its horizon. I would suggest that any concept of the political that does not incorporate democracy and equality as constitutive of its meaning and as irreducible falls short as a definition, not merely normatively. At the same time I want to insist, as I did in the opening section, that the connection between the political and the state is contingent, a historical achievement and nothing more. If the operational requirements of the political system have short-circuited democracy to the state, only in terms of which the demos could be seen to act under systems of representation that were largely held as adequate (though against which other configurations of constituency, typically class, leveled their challenge), democracy was of course never exhausted in its state form. Industrial democracy, radical forms of syndicalism, or class struggle, to take some examples, were animated by and geared to the aspiration of democracy and equality but never came under the sign of state politics. Crosscutting and undercutting identifications mark the history of democratic struggle as a struggle over and against political ascriptions and given semantics. I do not intend, of course, to present a full defense of the political, but I want to set a background against which to take issue with the problem that "the political" in its various reentries as thematized, that is, in subsystems and aligned to subsystemic rationality, abandons in the process something fundamental about its organizing principle (democracy) and horizon (equality). If that is the case, the passage from "external" to "internal" politicization is problematic, and constitutional reflexivity will be called upon not as a facilitating, but crucially as a blocking device. My focus and interest within the broader theory of societal constitutionalism is in the relationship between politics and economics. My suggestion is to recruit constitutional reflexivity in a political role of guiding the selective withdrawal of certain areas of social action from the logic of price.

There is a structural reason why such a political role for constitutional reflexivity cannot be entrusted to "internal" politicization. It has to do with what is constitutive of economic reason. If the political is constitutively oriented to democracy and equality, any actual instantiation and program measured against their promise, the economic, under conditions of functional differentiation and subsystemic autonomy, has effectively removed the processes of the organization of production from its field of reference. The economically rational is measured in terms of how scarce means are allocated to competing ends against the background or in the context of "substitutable choices." "Economics," as Foucault puts it in an important lecture, "is no longer the analysis of the historical logic of processes; it is the analysis of the 
internal rationality, the strategic programming of individuals' activity" 68 of allocating, as we said, scarce means to alternative ends. This reorientation of economic reason away from a logic of needs and toward "the stud[y of] human behavior as a relationship between ends and scarce means which have mutually exclusive uses"69 has the effect of cutting it off from the problematic of utility as measured against social need and the problematic of participation in collective labor, let alone the aspirations of social justice and equality. André Gorz, among many here, has traced with extraordinary acuity how older problématiques of justice have been effectively displaced by an economic reason centered on efficiency, with specific reference to the changing landscape of work. ${ }^{70}$ Of course, such a radical reorientation of a field around new sets of "guiding distinctions" will generate paradoxes and tautologies. We know this well from Luhmann. "What is an income?" asks Yale economist Irving Fisher. ${ }^{71}$ An income is quite simply the product or return on a capital. Conversely, he says, we will call "capital" everything that in one way or another can be a source of future income. This closure of economic reason around its own self-descriptions, these tautologies, will call for a reflexivity to take care of the blockages. But in the process, it effects a displacement on the organizing principles of the political economy. The very injunction that capitalism dispossesses the worker in substituting the value of the lived intelligibility and meaning of work with an exchange value for labor becomes unintelligible. Economic reason makes redundant the notion of the political sphere itself as far as production is concerned. We do not need to delve into this subject much longer to see the following point: any passage between "external" and "internal" politicization is no passage at all. Of course, no systems theorist would ever contemplate that common meanings might be transferred across systemic boundaries. But for us, concerned with reflexivity and the logic of couplings, what might we still insist is communicated at the level of hybrid metacouplings? To be more precise, at the metacoupling of politics and economics, what survives entry into economic reason as the distinction between "le politique-la politique" i.e., as economically "politicizable" in the direction of the common interest? How would the economy visit the question of value other than from the point of view of exchange-value? Going back to the 1844 Manuscripts, what does it mean to protect the dignity of the worker

68. FoUCAULT, supra note 16 , at 223.

69. GaRY S. BECKer, THE ECONOMIC APPROACH To HuMan BeHavior 3 n.3 (1976) (quoting L. ROBBINS, THE NATURE AND SIGNIFICANCE OF ECONOMIC SCIENCE 16 (1962)).

70. See GOR2, supra note 23.

71. FOUCAULT, supra note 16, at 224 (quoting Irving Fisher). 
when, as Marx insisted, the worker, and not just work, was the "product of capital?"

The problem is that with the "reentry" into the other system's rationality, the political ceases to impact, underdetermined to the point at which it is in all cases productive to the receiving system and realigned to its functional imperatives. If we expect a limitative role from the constitutional, then "public responsibility," a moment of the political-must furnish an "additional reflection" or independent criterion; it cannot fold seamlessly back into the logic of the reproduction of the system. This is Teubner's point. But what, one may ask, in the rationality of allocation of scarce means to alternative ends might impact as protection of the common good? What in the practice of activist shopping will stand it apart, a barrier to hitting the bottom, the expression of a superior notion of the common good that is not always already cashed out in terms of consumerism and hollowed out, to borrow from Lilian Moncrieff's critique of politicized consumerism, from the political demand "one consumer, one vote" to its economic counterpart "one consumer, one purchase?"72 The political actor is emphatically not the conscientious consumer; if activist shopping is the "economic expression" of the "political," then there is something fundamentally wrong with these "reentries." For one, flip "activist shopping" onto the negative: opposition to consumerism is evidently not the same, it is not equivalent, and it is not even symmetrical to political apathy. The key question and test for the reflexivity of societal constitutionalism is whether it can put the market to question as an appropriate register for a series of issues that any decent society with a fundamental commitment to the dignity of its members would not choose to commodify. Would a reflexive coupling allow some kind of return to thinking of the political economy that incorporates democracy in production as irreducible value (irreducible, that is, to functional equivalents)? Cutting through the logic of functional equivalence via political decisions is absolutely vital here, and the imperative is rendered vacuous if democracy is "always-already" aligned to market recalibration through the logic of function and equivalence. Perhaps there is some room here for complexity and nuance. My intention was to explore with Teubner, in terms of the resources that "societal constitutionalism" offers, whether such a move to rein in commodification and the ideology of the "total market," in the name of the common good, might be possible. This requires us to return one more time to constitutional reflexivity, and scrutinize how it functions

72. Lilian N. Moncrieff, Bound to Shop: Corporate Social Responsibility and the Market (Jan. 19, 2011) (Ph.D thesis, University of Glasgow) (forthcoming Jan. 2014). 
at the metalevel. My conclusions may differ from Teubner's, but the departure is the same, if more narrow: to look at how law and the economy pivot on the political to each sustain their own reflexivity. Without that pivot and that reliance, no metalevel reflection can be sustained and no possibility to think the "limitative" exists. This is quite clear I think when it comes to law and how constitutional lawyers talk about it. If constitutional reflexivity is metalevel thinking, it is only the orientation of the constitution in a political direction that makes it possible. Teubner too talks about such reflexive coupling, and his writing includes thinking that constitutionally, law "domesticates" that rationality, though that is not the issue here. The issue is that the metalevel thinking becomes possible because of the political dimension; a law cannot simply renew itself in a blind positivity of its self-reproduction, but must measure it against, and seek orientation from, the political moment to reproduce itself as a stable order of normative expectations in its temporal, social, and material dimensions. That is the achievement of constitutional reflexivity: the rationalization of law as informed by the organizing constitutional distinction, the guiding difference constituent or constituted, whose two poles stand opposed and asymmetrical, an asymmetry that is creatively unfolded on both sides. I do not want to digress too much, but let me note here that law too can be coupled at the reflexive level with either politics (as above) or the market. In each case, first-order operations are tested against the truth values of the second level (veridiction) that is produced via reflexive couplings. Foucault tells the story of the rise of the market system (at roughly the same time as Polanyi, between 1750 and 1830) very much as the story of such a coupling of law with the market as site of veridiction..$^{73}$

For public law, whose means of calibration and self-limitation had relied so far on what could be identified as an expansionist eigen-dynamic, the emergence of the market system plays the role of catalyst. The law is confronted with the "truth" of natural equilibria. Against this truth it can measure the legitimacy of its intervention. The rationale of self-limitation acquires an external measure with the help of which a role proper for public law is fashioned. A coupling now ensures the proper self-limitation of power and crucially, (jurisdiction "one must not govern too much" is granted a means to rationalize "excess"), it ensures the orientation of public law in terms of a guiding distinction of public or private that delimits proper spheres of application and a rationale for intervention and connects the perennial

73. FouCAULT, supra note 16, at 27-50. 
quest for legitimacy to the veridiction of the market. ${ }^{74}$ With veridiction, the stakes are raised and, significantly, the reflexive question is imported through a different metalevel coupling. The market as the correlative or accompanying self-reference now sets the criteria of "correct" choices. Could it be then that the economy too can only pull itself on to the reflexive plane with the help of the political, and thus also attempt the reining in of its blind self-reproduction on the register of the political economy? Only here can the limitative be fashioned as something capable of providing the independent criterion as that which suspends, in certain spheres, the self-reproduction of an economy that insatiably commodifies and feeds off its own aggressive expansion. In this suspension, reflexivity becomes the blocking device; it withdraws certain issues, such as the protection of collective agreements, from economic determination.

Here is the problem for the metalevel of the economy as I see it. The economic system hoists itself reflexively onto the metalevel via the distinction "in the public interest or not in the public interest" such that, contentless, is too underdetermined to sustain it on that plane. Either it seeks the criteria of what might fashion it as an independent, reflexive inquiry, through political criteria, or it seeks them in the logic of price (CSR, activist shopping), which cannot sustain it at the metalevel, and collapses it back to the functional level. Of course, nothing guarantees the range and resilience of those political determinations that uphold the "constitutional" of economic constitutionalism. Often they are simply incongruous, stubborn attempts to hold the line. Take the example of the constitutionalization of social dumping that is the European Court of Justice's (ECJ's) recent decisions (Laval and Viking, for example) ${ }^{75}$ on

74. That it discovers a certain naturalness specific to the practice of governance itself is key here. Never before-Polanyi has put it so brilliantly in talking about the homo economicus in Adam Smith's account of economic rationality in man-had such a misreading of what comes naturally to man been so prophetic. The role of the "natural"-in this crucial sense of human nature-subtends the operation of public law, providing it with a rationale for actions, limits, crucially its measure. And yet it is never anything except the projection from within the logic of governmentality of its object: the substratum of the govern-able. "It is," he says, "if you like, its indispensable hypodermis." Id. at 16. It is to this self-referentiality of law that the market gives leverage. In fact without it, Foucault tells us (if not in these precise terms), the self-referentiality could not pick itself up off the ground. "[The] action [of the governors] has an underside, or rather, it has another face, and this other face of governmentality, its specific necessity, is precisely what political economy studies. It is not background, but a permanent correlative." (Id. at 16 (emphasis added). It is this accompanying self-reference, this naturalness in respect of which the action of government unfolds.

75. Case C-341/05, Laval un Partneri Ltd v. Svenska Byggnadsarbetareförbundet, 2007 E.C.R. I-11767; Case C-438/05, Int'l Transp. Workers' Fed'n v. Viking Line ABP, 2007 E.C.R. I-10779. 
issues of social protection and industrial action. Christian Joerges's "solution" is a direct affront to market integration: respect Finnish law, he suggests, and respect the efforts of trade unions to coordinate labor interests transnationally. "I fear," he says, "that there is no third way here except the stubborn insistence to protect the achievements of Finnish law in this case."76 Another example is Wolfgang Streeck's call for a "democratic departure from the life-threatening sedation provided by cheap-money capitalism" involving the "revitali[zation of the] trade union movement" across frontiers in Europe. ${ }^{77}$ In each case, the reflexivity of the economic constitution is harnessed to political criteria and informed by political reflexivity. What is significant about the difference? It is that reflexivity here is not an invitation to the economy to think in the public interest; it is an injunction against the commensurability of claims. It is a political injunction against the "pooling" of freedoms of workers and entrepreneurs to strike and to reflag respectively and against the flattening device of "proportionality" that allows "the balancing" of labor rights against economic rights. It is therefore an injunction against the submission of the dignity of labor to the economic reasoning of comparative advantage. Any assumed passage from external to internal politicization cancels out the injunction and collapses the reflexivity in the guise of merely transferring them onto the plane of economic reason.

\section{CONCLUSION}

In a circuitous way, and one which I had not set off to follow, we have arrived back to societal constitutionalism at the metalevel with a clearer view of the stakes and of the dilemma facing us. I have warned against the logic of functional equivalence and have argued that a critical systems theory must embrace a political reflexivity if it is to claim back democratic self-understandings and epistemological premises that have come increasingly to measure themselves against the market as a site of veridiction. And perhaps also we are now in a position to raise otherwise the reflexive question over what is societal about societal constitutionalism. The double slippage that we began with now becomes clearer as the dilemma that confronts us between politics or the market as that which sustains constitutional reflection. Against the danger of market capture, where the market calls forth the "societal" by submitting it to functional imperatives, and, in the final

76. Christian Joerges, Will the Welfare State Survive European Integration? 1 EUR. J. Soc. L. 4, 17 (2011).

77. Wolfgang Streeck, Markets and Peoples: Democratic Capitalism and European Integration, 73 NEW LEFT REV. 63, 70 (2012) (emphasis added). 
instance, harnessing it to market allocations, we are invited to rethink it along the political dimension as political economy. Let us strive to take that opportunity while it still remains meaningful, before the collapse of democratic categories into market thinking seals over the space where a politics is still possible without the logic of price. 
